THOMAS F. BRADSHAW

Bureau of Labor Statistics

JANET L. SCHOLL

Bureau of Labor Statistics

\title{
The Extent of Job \\ Search during Layoff
}

IN A RECENT Brookings paper, Martin Feldstein emphasized the importance of temporary layoffs in the total unemployment count, particularly during recessions. ${ }^{1}$ Feldstein presented evidence showing the lack of job search among laid-off workers as well as their high probability of recall. He concluded that search theory and Phillips-curve analysis may have gone astray in failing to account for temporary layoffs. While Feldstein has performed a service in pointing out the significance of this group, we feel that he may have drawn some unwarranted conclusions about the extent to which persons on layoff search for work.

Feldstein uses three sources of data-the National Longitudinal Survey of the U.S. Manpower Administration, and the Establishment Survey and the Current Population Survey of the U.S. Bureau of Labor Statistics. Data from both the National Longitudinal and Establishment Surveys are used to demonstrate that a high proportion of laid-off workers return to the jobs they formerly held. Only the data from the Current Population Survey (CPS) are used as evidence of the lack of job search among persons on layoff. Because Feldstein estimates that only 10 percent of laid-off workers search for other jobs, he questions search theories that "equate unemployment with search and job change." Feldstein further suggests the need for revising the explanation of the short-run Phillips curve by Fried-

Note: The opinions expressed are those of the authors and do not necessarily represent the views of the Bureau of Labor Statistics or the Department of Labor.

1. Martin S. Feldstein, "The Importance of Temporary Layoffs: An Empirical Analysis," BPEA, 3:1975, pp. 725-44. 
man and Phelps because "so much of the cyclical variation in unemployment reflects the temporarily laid off, who do not search. ...". Thus, because the job search of laid-off workers is the crucial question in his paper, we will attempt to assess whether Feldstein correctly interpreted the CPS job-search information he obtained and examine what additional information is available on this question.

\section{Feldstein's Evidence on Job Search}

Feldstein's empirical evidence on the extent of job search among laid-off workers is based on responses to question 19 of the Current Population Survey conducted in March 1974. This is the introductory question on employment status: "What was _____ doing most of last week?" According to the responses, only 10 percent of the workers on layoff were "looking for work"; the percentages of those on fixed and indefinite layoff were 3.8 and 12.4, respectively. ${ }^{3}$ These figures are deceptive since this question was not designed to measure job-search activity. It is merely the first of a series of questions which ultimately determine a person's labor-force classification. Thus, some problems arise in using responses to it as evidence about job search.

First, actively looking for work may consume a small portion of time for many unemployed persons; in any job search, active pursuit of job offers normally alternates with awaiting the outcome of previous efforts. Therefore, many of the unemployed would not report "looking for work" as their major activity, even though they did spend some time searching during that week. According to a special CPS survey in January 1973, over threefifths of those unemployed in 1972 looked less than five hours a week for a job. ${ }^{4}$

Second, and probably more important, CPS interviewers are instructed to classify those who say they are on layoff in response to question 19 as

2. Ibid., pp. $739,740$.

3. For Feldstein's complete table, see ibid., p. 732. The term "fixed duration" refers to the CPS "temporary layoff" group-those expecting recall within thirty days. It should be noted, however, that persons on layoff more than a month frequently classify themselves as on temporary layoff even though they have not been recalled within thirty days.

4. U.S. Bureau of Labor Statistics, Jobseeking Methods Used by American Workers, BLS Bulletin 1886 (Government Printing Office, 1975), table H-2, p. 51. 
"with a job but not at work" rather than as "looking for work." Consequently, regardless of the amount of job seeking that these people engaged in, none is recorded. Later questions in the CPS are designed to identify those on layoff not picked up by question 19. However, these people are not asked if they have been looking for work in the past four weeks. In summary, people on layoff are recorded as "looking for work" in the tabulations of the responses to question 19, on which Feldstein relied, only if their layoff status was not conveyed to the interviewer at that point and they searched most of the reference week.

Given these problems with using data derived from the regular CPS schedule, we sought additional sources that might more accurately portray the extent of job search among those on layoff.

\section{Proportion Who Search}

Several surveys provide direct evidence that a high proportion of persons on layoff look for work. One of these is the Job Finding Survey, a set of supplementary questions to the January 1973 Current Population Survey. Persons in the CPS sample who were currently employed and who were not working at their present job throughout the prior year were asked to complete a questionnaire on their job search ${ }^{6}$ Thus, the survey included those who returned to their previous employers as well as those who found new jobs. The survey, of course, consists of a somewhat biased sample in that it is limited to "successful" job seekers (those who obtained a new job or returned to an old one). Conceptually, the definition of layoffs in the Job Finding Survey is the same as that in the regular CPS. However, these measures are not completely comparable because the two surveys use different series of questions to determine layoff status and refer to time periods of different lengths. Of the total group identified as being on layoff in the Job Finding Survey, 83 percent said they looked for work before they

5. U.S. Bureau of the Census, “Current Population Survey: Interviewer's Reference Manual” (December 1971; processed), p. D6-6.

6. See BLS, Jobseeking Methods, for a description and a copy of the questionnaire. Persons were included in the Job Finding Survey if they started to work for their current (January 1973) employer during 1972. Also included were those who had worked for the same employer more than once but started their present employment during 1972 (for example, those who returned to their jobs after being on layoff during 1972). 
either returned to their old job or obtained a new job. ${ }^{7}$ These nationwide results suggest that a much larger proportion of workers on layoff engaged in job search than Feldstein estimated.

A second, more detailed study of job search is the Sheppard and Belitsky survey of blue-collar workers in Erie, Pennsylvania. ${ }^{8}$ This sample was drawn from State Employment Service files of registrants from January 1963 to March 1964, a period of high unemployment in that locality. All of the respondents had recent work experience and most had been laid off from manufacturing and construction firms. By the time of the interviews, in the fall of 1964, most were employed-41 percent at their old jobs and 36 percent at new jobs. ${ }^{9}$

Sheppard and Belitsky reported that a large majority of the blue-collar workers expected at the time of layoff to be called back (71 percent). Nevertheless, two-thirds of the total (both those who expected to be called back and those who did not) looked for work during layoff, and over half (53 percent) started to look within two weeks of layoff. ${ }^{10}$ The proportion of laid-off workers who searched is lower than the 83 percent reported in the Job Finding Survey. One reason is that Sheppard and Belitsky interviewed those who were still not working as well as those who had found jobs. The important finding from both surveys, however, is that a substantial proportion of persons on layoff do look for work.

As the result of a recent revision, the Canadian Labour Force Survey (CLFS) now includes several questions relating to the job search of persons on layoff; it is the one periodic survey that does so. ${ }^{11}$ Like the CPS, the Canadian survey covers a nationwide sample; in fact, it has a larger sampleto-population ratio. In general, the two use the same labor-force concepts. However, in practice, layoffs in the CLFS must conform to a stricter definition than that used in the CPS. In the CPS, persons absent from a job because of layoff are asked if they have a definite recall date within thirty days. If the response is "yes" they are classified as on "temporary layoff" and if the response is "no" they are classified as on "indefinite layoff."

7. Computed from unpublished data from the Job Finding Survey. Unfortunately, information from this survey was not tabulated by whether persons returned to the same employer or found new jobs.

8. Harold L. Sheppard and A. Harvey Belitsky, The Job Hunt: Job-Seeking Behavior of Unemployed Workers in a Local Economy (Johns Hopkins Press, 1966).

9. Ibid., table 2-2, p. 18.

10. Ibid., table $3-3$, p. 35 , and table 3-1, p. 32 .

11. For a description of the survey, see Ian Macredie and Bruce Petrie, "The Canadian Labour Force Survey" (Ottawa: Statistics Canada, Labour Force Survey Division, 1976; processed). 
Those in the "indefinite" group (over four-fifths of all layoffs in 1975) are not asked specifically whether they anticipate recall. In contrast, all those in the CLFS who attribute their absence from work to layoff must expect to return to that job before they can be classified as on layoff. During 1975, layoffs accounted for less than 15 percent of unemployment in Canada, compared with over 20 percent in the United States. ${ }^{12}$

Data from the Candian survey indicate that in 1975, on average, about 20 percent of all persons on layoff had looked for work in the six months prior to being interviewed. Nearly 90 percent of these had also searched in the last four weeks. ${ }^{13}$ There are several major differences between the Canadian survey and the other two surveys that may explain why the CLFS showed substantially fewer persons searching for work. First, the Canadian definition of layoffs is restricted to those who expect to be recalled; in the Sheppard and Belitsky sample, 29 percent did not expect recall. People who definitely expect to be recalled may be less likely to search. Second, the Canadian survey questions on job search refer to specific time periods (either four weeks or six months), whereas the periods for job search are not limited in the other two surveys. Third, the questions in the CLFS relating to whether persons searched for work are open-ended. This type of questioning often results in an underestimate of the amount of job search because many respondents do not believe that the informal methods they use, such as asking friends and relatives, are considered legitimate search techniques. The other two surveys probe extensively for all types of job-search efforts.

To summarize, despite limitations of comparability among these surveys, all three of them pointed to more job search among persons on layoff than Feldstein found in the CPS data.

\section{Extent of Job Search}

Aside from compiling direct evidence on the proportion of laid-off workers who search for jobs, we have examined the question of whether they spend as much time and use the same methods as other job seekers do.

12. The U.S. figure is computed from unpublished annual-average data from the CPS. The Canadian figure is derived from Statistics Canada, "The Labour Force Historical Series-Unadjusted and Seasonally Adjusted Data, January 1970-December 1975" (Ottawa: Statistics Canada, 1976; processed), and from Richard Veevers, "Persons on Layoff: As Measured by the RLFS" (Statistics Canada, Labour Force Survey Division, 1976; processed).

13. Ibid., table 5 . 


\section{DURATION}

Workers on layoff are frequently characterized as delaying job search until their unemployment insurance benefits near exhaustion. However, the Job Finding Survey indicates that four-fifths of the job seekers who were on layoff began looking for work before their third week of unemployment. Over half (58 percent) started their job search either before or within one to two days after layoff. ${ }^{14}$ Although Feldstein's argument suggests that people on layoff delay job search because they expect to be recalled, only 30 percent of those on layoff who delayed beyond a day or two gave this as their main reason for doing so. ${ }^{15}$

Another indicator of the intensity of job search is the total number of weeks spent looking for work. According to the Job Finding Survey, over half (53 percent) of the workers on layoff who searched did so for at least five weeks before finding a job, compared with 38 percent of other job seekers. One-fourth of the laid-off job seekers spent fifteen or more weeks in search, compared with 14 percent of job seekers who were unemployed for other reasons..$^{16}$ Although we do not have a measure of actual hours of job search for laid-off workers, the data on duration of search suggest that the amount of time (weeks) they spent looking is greater than that spent by other job seekers.

\section{METHODS}

Many have thought that laid-off workers limit their job-search efforts to required trips to the state employment office. Relying again on data from the Job Finding Survey, we find that persons on layoff who searched for work used on average more methods than did all job seekers (4.7 compared with 4.0). And they chose methods just as diverse (see table 1). Among the major differences appears to be that those on layoff make greater use of friends and relatives, state employment offices, and union hiring halls. In the Sheppard and Belitsky survey, most blue-collar workers cited friends and relatives as their usual source of job information. (Three-fourths of layoffs in 1972 originated in blue-collar occupations. ${ }^{17}$ ) That persons on layoff

14. BLS, Jobseeking Methods, tables F-1 and F-2, p. 45, and unpublished tabulations.

15. Ibid., table F-3, p. 46, and unpublished tabulations.

16. Ibid., table G-4, p. 48 , and unpublished tabulations.

17. Unpublished annual-average data from the CPS. 
Table 1. Job-Seeking Methods Used by All Seekers and by Those on Layoff, and Average Number of Methods Used, 1972

Percent of job seekers

\begin{tabular}{|c|c|c|}
\hline Method & $\begin{array}{c}\text { All } \\
\text { job seekers }\end{array}$ & $\begin{array}{c}\text { Job seekers } \\
\text { on layoff }\end{array}$ \\
\hline Applied directly to employer & 66.0 & 70.0 \\
\hline \multicolumn{3}{|l|}{ Asked relatives } \\
\hline About jobs where they worked & 28.4 & 35.7 \\
\hline About jobs elsewhere & 27.3 & 33.8 \\
\hline \multicolumn{3}{|l|}{ Asked friends } \\
\hline About jobs where they worked & 50.8 & 56.5 \\
\hline About jobs elsewhere & 41.8 & 48.0 \\
\hline \multicolumn{3}{|l|}{ Answered newspaper ads } \\
\hline Local paper & 45.9 & 54.4 \\
\hline Out-of-town paper & 11.7 & 17.2 \\
\hline \multicolumn{3}{|l|}{ Placed newspaper ads } \\
\hline Local paper & 1.6 & 1.6 \\
\hline Out-of-town paper & 0.5 & 0.8 \\
\hline \multicolumn{3}{|l|}{ Made personal contacts } \\
\hline State Employment Service & 33.5 & 55.3 \\
\hline Private employment agency & 21.0 & 24.1 \\
\hline Union hiring hall & 6.0 & 17.9 \\
\hline Local organizations & 5.6 & 5.8 \\
\hline School placement office & 12.5 & 6.4 \\
\hline Took Civil Service test & 15.3 & 14.4 \\
\hline Asked teacher or professor & 10.4 & 5.4 \\
\hline Answered ads in journals & 4.9 & 4.2 \\
\hline Placed ads in journals & 0.6 & 0.5 \\
\hline Went to place where employers pick up job seekers & 1.4 & 1.9 \\
\hline Other & 11.8 & 11.7 \\
\hline \multicolumn{3}{|l|}{ Addendum } \\
\hline Average number of methods used & 4.0 & 4.7 \\
\hline
\end{tabular}

Source: U.S. Bureau of Labor Statistics, Jobseeking Methods Used by American Workers, Bulletin 1886 (Government Printing Office, 1975), p. 27.

contact public employment offices more often than other unemployed persons do reflects their greater eligibility for unemployment insurance benefits: all states require registration with the state employment service in order to collect these benefits. Union hiring halls are used more heavily, probably because most layoffs originate in the goods-producing sector where unionization is greater. Even though laid-off workers use these three methods more often than the average job seeker does, they do not rely solely on these methods. 
Table 2. Sources of Information about Job Openings and Job-Seeking Techniques Used by Blue-Collar Workers on Layoff, 1964

Percent of job seekers using each method

\begin{tabular}{lcc}
\hline \multicolumn{1}{c}{ Source or technique } & $\begin{array}{c}\text { Usual } \\
\text { sources of } \\
\text { information }^{\mathrm{a}}\end{array}$ & $\begin{array}{c}\text { Job-seeking } \\
\text { techniques }^{\text {used }}\end{array}$ \\
\hline Friends and relatives & 55 & 77 \\
Newspaper ads & 53 & 88 \\
State Employment Service & 34 & 84 \\
Coworkers & 15 & $\circ$ \\
Companies-direct application & 9 & 72 \\
Unions & 8 & 20 \\
Radio & 5 & $\circ$ \\
Private employment agencies & 3 & 17 \\
Government personnel offices & $\ldots$ & 27 \\
Religious, welfare, veterans', fraternal organizations, etc. & $\ldots$ & 18 \\
\hline
\end{tabular}

Source: Harold L. Sheppard and A. Harvey Belitsky, The Job Hunt: Job-Seeking Behavior of Unemployed Workers in a Local Economy (Johns Hopkins Press, 1966), pp. 44, 45.

a. Respondents were asked, "How do you usually hear or learn about companies that are looking for people to hire?" The question was open-ended.

b. Respondents were asked a series of questions about use of specific job-seeking techniques.

c. This technique was not specified by the questionnaire.

Data from the Sheppard and Belitsky study support our conclusion, based on the Job Finding Survey, that laid-off workers who search use a variety of techniques (see table 2). The most important sources of job information for the Erie sample of blue-collar workers were friends and relatives and newspaper ads. However, about three-fourths of those who looked also used the employment service and checked directly with company personnel offices.

The Job Hunt also provides some information on the job-search behavior of workers who return to their former employers. About 65 percent of these men had looked for work (see table 3 ). They used much the same job-search techniques as workers who found new jobs; between 70 and 90 percent of both groups relied on newspaper ads, the employment service, friends and relatives, and visits to company personnel offices. Call-backs (persons reemployed at their former jobs) who checked directly with employers visited an average of 8.5 companies compared with an average of 12.7 visits made by workers who found new jobs or were still unemployed. ${ }^{18}$ Although a smaller proportion of the call-backs looked for work, and they looked less

18. Job Hunt, table 3-18, p. 55. 
Table 3. Number and Percentage of Male Blue-Collar Workers on Layoff Who Looked for Work, and Percentage Using Selected Job-Seeking Techniques, by Current Employment Status, 1964

\begin{tabular}{lccc}
\hline \multicolumn{1}{c}{ Description } & $\begin{array}{c}\text { Reemployed } \\
\text { at old jobs }\end{array}$ & $\begin{array}{c}\text { Reemployed } \\
\text { at new jobs }\end{array}$ & $\begin{array}{c}\text { Still } \\
\text { unemployed }\end{array}$ \\
\hline Number in sample & 133 & 128 & 48 \\
$\quad$ Looked for work & & & \\
$\quad$ Number & 86 & 111 & 42 \\
$\quad$ Percent & 65 & 87 & 88 \\
Job-seeking technique (percent using) & & & \\
$\quad$ Newspaper ads & 85 & 91 & 86 \\
$\quad$ State Employment Service & 83 & 86 & 81 \\
Friends and relatives & 71 & 87 & 86 \\
Companies-direct application & 78 & 71 & 86 \\
Government personnel offices & 31 & 31 & 31 \\
$\quad$ Unions & 21 & 24 & 29 \\
Religious, welfare, veterans', fraternal & & & \\
$\quad$ organizations, etc. & 19 & 19 & 31 \\
Private employment agencies & 13 & 23 & 19 \\
\hline
\end{tabular}

Source: Sheppard and Belitsky, Job Hunt, table 2-1, p. 18, and table 4-2, p. 75.

extensively than other laid-off workers, their job-search efforts cannot be considered insignificant.

\section{Summary}

The data examined here call into question Feldstein's conclusion that very few workers on layoff are job seekers. Feldstein's primary data source, the CPS, is not designed to obtain job-search information from persons on layoff. Moreover, evidence from the Job Finding Survey, the Sheppard and Belitsky study, and the Canadian survey indicates that a greater proportion of those on layoff search for work than Feldstein suggested..$^{19}$

19. There is insufficient evidence to determine precisely what proportion of persons on layoff search for work. Given the range of 20 to 80 percent found through three independent sources, an estimate of 50 percent seems reasonable.

A special supplementary questionnaire to the May 1976 Current Population Survey will provide more information on the job search of workers on layoff. The survey questioned unemployed persons (including those on layoff) about their job-search activities-methods, rejection of job offers, and receipt of unemployment insurance. Results from this more comprehensive survey will be available in early 1977 from the Office of Current Employment Analysis, Bureau of Labor Statistics. 
We also found evidence that job-search efforts by those on layoff were comparable to those of other job seekers. According to the Job Finding Survey, over half of the workers on layoff began looking before or immediately after layoff. They also spent more weeks in job search than did other job seekers. Both the Sheppard and Belitsky and the Job Finding studies show that workers on layoff used a variety of search techniques. Finally, using the information on reemployment status developed by Sheppard and Belitsky, we were also able to determine that even workers who went back to their former employers searched a significant amount.

\section{Discussion}

MARTIN FELDSTEIN was pleased to learn that the Bureau of Labor Statistics had conducted a survey in May 1976 investigating the search activities of people on layoff. He felt that the results from the survey would fill an important gap in knowledge since he did not believe that any of the currently available data sources was adequate. Feldstein acknowledged the deficiencies in his own work using the Current Population Survey that Bradshaw and Scholl had pointed out; but he argued that, with the exception of the Canadian Labour Force Survey, which had produced results that seem quite consistent with his paper, the studies cited in the BradshawScholl report were also unsuitable for investigating the question at hand. The Job Finding Survey had been designed to investigate the effectiveness of alternative search methods and included only workers who had begun their "present jobs or businesses" in 1972. As the authors acknowledge, this limited the survey to those who did become employed. Although the survey indicates that workers on temporary or indefinite layoff who changed jobs did engage in search, it provides no evidence on the extent of search among the vast majority of those on layoff who did not change jobs. An additional bias might have entered if laid-off workers were not fully sampled, since they were included only if they responded correctly to a separate question that he found ambiguous. Thomas Bradshaw expressed the belief, based on CPS annual-average data, that the Job Finding Survey did not miss a large number of persons on layoff. 
Feldstein also argued that the sample for the study by Sheppard and Belitsky was atypical since it used workers who had registered at the State Employment Service; by the action of registration, members of this group had indicated that they were engaging in search activity. Janet Scholl disagreed that this factor presented a serious bias since registration was required in order to collect unemployment insurance. She also observed that those on layoff had not simply registered but had, in addition, used other search methods similar to those of other job losers. Feldstein noted that this "active search" might also have been required to collect unemployment insurance. R. J. Gordon pointed out that the Sheppard and Belitsky study had been made during a period of high unemployment and that this might also bias the result toward indicating abnormally high search activity. Charles Holt stressed the importance of collecting data over the complete cycle so that a full picture of search behavior could be constructed; layoff and quit rates are very sensitive to labor-market tightness.

Martin Baily argued that the evidence that over three-quarters of those unemployed in 1972 looked for a job for less than five hours a week cast doubt on the search paradigm, in which it is assumed that workers leave work because they cannot work and look for a job at the same time. Holt pointed out, however, that waiting might have to accompany search activity; thus, if the five hours could not be freely chosen over the week, they might indeed interfere with holding a full-time job.

Robert Hall and Edward Gramlich stressed that Feldstein's principal finding, that a high percentage of layoffs ended in recall, had not been brought into question, although Hall and Bradshaw cited evidence that Feldstein's estimate of an 85 percent rehire rate would be lower, perhaps in the neighborhood of a two-thirds rate, if corrected for transfers within a firm. As Gramlich noted, the high recall rate implied a flat Phillips curve in which people would return to their old jobs, presumably at their old wage rates, so that the employment of this group was not related to its wage rate. He felt that the evidence on search activity might call for a small modification of our understanding: if those temporarily laid off were searching, it might give others the illusion of a greater degree of excess supply than there actually was. Arthur Okun noted that this meant that surveys should distinguish between people who were looking for stop-gap jobs while awaiting recall and those looking for a new permanent job.

Gordon and Robert Solow pointed out that the significance of Feldstein's paper had not depended upon whether people on layoff searched or 
not. What really mattered was why people were unemployed. Feldstein's evidence on layoffs indicates that it is shifts in demand that place people in the involuntary situation of not working. It is not, as some have suggested, that price changes cause voluntary decisions on the part of firms to alter their output, and on the part of workers to move in and out of employment. The direction of causation was from output to prices and not the other way around. 